\title{
Distal Bile Duct Cancer pT4 TNM Finding v7
}

National Cancer Institute

\section{Source}

National Cancer Institute. Distal Bile Duct CancerpT4 TNM Finding v7. NCI Thesaurus.

Code C90252.

Distal bile duct cancer with tumor involving the celiac axis or the superior mesenteric artery. (from AJCC 7th Ed.) 